\title{
Electron paramagnetic resonance spectroscopic investigation of the inhibition of the phosphoroclastic system of Clostridium sporogenes by nitrite
}

\author{
Martin J. Payne, ${ }^{1 *}$ Leonard F. J. Woods, ${ }^{2}$ Paul Gibbs $^{2}$ and Richard Cammack ${ }^{1}$ \\ ${ }^{1}$ Department of Biomolecular Sciences, King's College London, Campden Hill Road, Kensington, London W8 7AH, UK \\ ${ }^{2}$ Microbiology Section, Leatherhead Food Research Association, Randalls Road, Leatherhead, Surrey KT22 7RY, UK
}

(Received 25 April 1990; accepted 13 June 1990)

\begin{abstract}
The proposal that nitrite exerts its inhibitory effect on anaerobic bacteria by direct interaction with the ironsulphur proteins of the phosphoroclastic system was investigated. The effects of nitrate, nitrite with or without

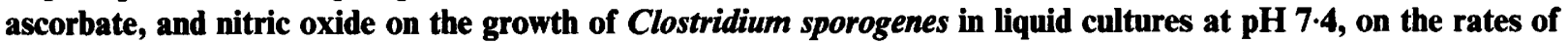
hydrogen production, and on the activities of the enzymes pyruvate-ferredoxin oxidoreductase and hydrogenase, and of ferredoxin were investigated. In agreement with previous studies, nitrate was the least effective inhibitor of cell growth, and nitric oxide the most effective. Nitrite reductase activity was very low in $C$. sporogenes, indicating that the presence of external reducing agents would be necessary for the reduction of nitrite to nitric oxide. Inhibition by nitrite was enhanced by ascorbate; $0.5 \mathrm{mM}$-nitrite with $10 \mathrm{mM}$-ascorbate stopped growth completely. In partially-purified preparations $4 \cdot 1 \mathrm{mM}-\mathrm{NaNO}_{2}$ and equimolar ascorbate caused complete inactivation of hydrogenase activity but only partial (up to $78 \%$ ) inactivation of pyruvate-ferredoxin oxidoreductase. This agreed with the loss of hydrogen production observed with nitrite in vivo. Inhibition occurred within $5 \mathrm{~min}$, and was irreversible in each case. Electron paramagnetic resonance (EPR) spectroscopy showed that paramagnetic $\left[\mathrm{Fe}(\mathrm{NO})_{2}(\mathrm{SR})_{2}\right]$ species were formed during growth in the presence of nitrite, and were associated with cells. However, the intensity of these EPR signals did not correlate with the inhibition of cell growth. The [4Fe-4S] clusters in ferredoxin were shown by EPR spectroscopy to be resistant to treatment with $3.6 \mathrm{mM}-\mathrm{NaNO}_{2}$ and $3.6 \mathrm{mM}$-ascorbate. It is concluded that the effects of nitrite on pre-formed iron-sulphur proteins are not convincing as a basis for the lethal effects on bacterial cells.
\end{abstract}

\section{Introduction}

Nitrate and nitrite are preservatives used widely to inhibit the growth of clostridia in foods such as meat. The bacteriostatic effect of nitrate operates mainly through reduction to nitrite, which is further converted to other inhibitory species. The effects of these compounds are enhanced by reducing agents, such as ascorbate, which are added to meat products as stabilizers. The maximum $\mathrm{NaNO}_{2}$ concentrations used in bacon, sausage, ham and other cured meats are around $0.03 \mathrm{mg}$ (g food) $)^{-1}$ (Knight et al., 1987), which corresponds to approximately $0.4 \mathrm{~mm}$-nitrite. Inhibition of clostridial growth by nitrate and nitrite has been widely studied over the past 20 years. These studies have involved a wide range of species and growth media ranging from fluid-broth to meats (Roberts \& Ingram,

\footnotetext{
Abbreviations: DTT, dithiothreitol; [Fe-S-NO], iron-thiol-nitrosyl complex.
}

1966; Perigo et al., 1967; Perigo \& Roberts, 1968; BairdParker \& Baillie, 1973; O'Leary \& Solberg, 1976; Woods et al., 1981; Woods \& Wood, 1982). The bacteriostatic action of $\mathrm{NaNO}_{2}$ in these systems is enhanced when it is reduced by ascorbate (Tompkin et al., 1978 $a, b$; Pierson \& Smoot, 1981).

Perigo \& Roberts (1968) found that when nitrite was heated with reinforced clostridial medium at $\mathrm{pH} 6-7$, the nitrite disappeared and the medium became more inhibitory to clostridial growth. This is referred to as the 'Perigo effect', and is due to the heat-dependent formation by nitrite of more powerful inhibitors, termed 'Perigo-type factors' (Larkworthy et al., 1977). Various inhibitory species, such as $S$-nitrosocysteine and Roussin's black salt, $\left[\mathrm{Fe}_{4} \mathrm{~S}_{3}(\mathrm{NO})_{7}\right]$ (Asan \& Solberg, 1976), have been isolated from meats after nitrite addition. However, these have not been found in sufficient quantities to account for the levels of inhibition observed. 
Evidence has been presented that nitrite acts upon metalloproteins which are essential for bacterial growth. Tompkin et al. (1978c) noted that excess iron caused a decrease in the effectiveness of nitrite inhibition of cell growth, and suggested that nitric oxide formed complexes with iron-sulphur proteins such as the clostridial ferredoxins, which are essential for electron transport, enzyme activity and energy production. Iron-sulphur complexes are reactive with nitric oxide, forming a range of iron-thiol-nitrosyl ([Fe-S-NO]) complexes (Butler et al., 1988). The phosphoroclastic system contains three iron-sulphur proteins: pyruvate-ferredoxin oxidoreductase, ferredoxin and hydrogenase. The inhibition of this system would be an effective way of inhibiting spore germination and cell growth.

Woods et al. (1981) found that when nitrite was added to a suspension of $C$. sporogenes cells in glucose medium, it resulted in a decrease in intracellular ATP and an accumulation of pyruvate in the medium. Similarly in C. botulinum cells, nitrite caused a decrease in intracellular ATP (Woods \& Wood, 1982). It was concluded that the inhibition of the phosphoroclastic system of $C$. sporogenes by nitrite involved the reduction of nitrite to nitric oxide, and that inhibition was likely to occur by attachment to the non-haem iron centres present in ferredoxin and pyruvate-ferredoxin oxidoreductase. Pyruvate-ferredoxin oxidoreductase activity was inhibited to a greater extent than ferredoxin activity (Woods et al., 1981). The activity of ferredoxin, in an NADH-linked assay, as electron acceptor from pyruvate-ferredoxin oxidoreductase was unaffected by preincubation with $6 \mathrm{~mm}$-sodium nitrite. The inhibitory action of nitrite on the phosphoroclastic system was not as evident in vitro as in vivo (Woods \& Wood, 1982).

Angermaier \& Simon (1983) studied the hydrogenase and ferredoxin-mediated reduction of aliphatic and aromatic nitro-compounds in clostridia, and proposed that nitrite possibly reacted with cysteine residues with the formation of stable $S$-nitrosothiols, thereby releasing the iron and sulphur from the clusters. However, Reddy et al. (1983) showed that cells of C. botulinum, after treatment with nitrite, yielded EPR signals with $g$-values of 2.02-2.04. This type of spectrum is characteristic of low-spin nitrosyl-iron complexes of the general formula $\left[\mathrm{Fe}(\mathrm{NO})_{2}(\mathrm{SR})_{2}\right]$ (McDonald et al., 1965), and has been observed in a variety of biological systems, including animal tissues, after treatment with nitrite (Vanin \& Varich, 1981). Reddy et al. (1983) proposed that the formation of these complexes from iron-sulphur proteins and nitric oxide was the mechanism of botulinal inhibition by nitrite in foods.

Carpenter et al. (1987) incubated C. botulinum cells with $14.5 \mathrm{~mm}$ nitrite, and estimated $94 \%$ inactivation of ferredoxin (assayed by monitoring the rate of reduction of cytochrome $c$ ) and $70 \%$ inhibition of pyruvateferredoxin oxidoreductase. They stated that it was likely that nitrite exerted its antibotulinal effect by the destruction of iron-sulphur enzymes within vegetative cells. In contrast to the earlier conclusions by Woods $e t$ al. (1981) they concluded that nitrite preferentially inhibited ferredoxin in vitro, although pyruvateferredoxin oxidoreductase activity was also inhibited.

We have investigated the mode of action of nitrite on the iron-sulphur proteins of the phosphoroclastic system of $C$. sporogenes. This organism is metabolically similar to the proteolytic strains of $C$. botulinum and $C$. perfringens, and therefore is useful as a model to investigate the inhibitory effect of nitrite and derivatives on food-spoilage bacteria. The direct effect of nitrite on the phosphoroclastic system in growing cells was studied by monitoring hydrogen production. The iron-sulphur proteins of the phosphoroclastic system, ferredoxin, pyruvate-ferredoxin oxidoreductase and hydrogenase, were studied in growing cells, in soluble cell extracts, and as the partially-purified proteins. They were incubated with nitrate, nitrite or nitric oxide, and changes in enzyme activities and the formation of EPR-detectable nitrosyl complexes were monitored.

\section{Methods}

Organism and growth conditions. Actively growing cultures of C. sporogenes, strain NCIB 10696, were inoculated $\left(10 \mathrm{ml} \mathrm{l}^{-1}\right)$ into Oxoid nutrient broth no. 2, containing $1 \%(\mathrm{w} / \mathrm{v})$ glucose and $5 \mathrm{ml} \mathrm{l}^{-1}$ of $10 \%(w / v)$ sodium thioglycollate, and incubated at $37^{\circ} \mathrm{C}$. Cell growth was monitored as optical density at $550 \mathrm{~nm}$. Cells were harvested by centrifugation after incubation for a further $20 \mathrm{~h}$.

Inhibitors. Nitrite was autoclaved in $10 \mathrm{l}$ of standard Oxoid nutrient broth no. 2, prior to the addition of glucose and thioglycollate. The nutrient medium was then inoculated with $10 \mathrm{ml}$ actively growing clostridia $1^{-1}$. Cells were incubated at $37^{\circ} \mathrm{C}$ for $24 \mathrm{~h}$ before harvesting. Nitric oxide was added to cultures as a saturated solution. Water was thoroughly saturated with oxygen-free argon before bubbling with nitric oxide on ice under anaerobic conditions, to avoid oxidation of $\mathrm{NO}$ and consequent acidification.

\section{Purification of proteins}

Soluble cell extracts. Extracts were prepared in an anaerobic glovebox (Miller Howe Ltd) in an atmosphere of nitrogen ( $<3$ p.p.m. $\mathrm{O}_{2}$ ). All buffers contained $1 \mathrm{~mm}$-dithionite. Cells stored under liquid nitrogen (approx. $50 \mathrm{~g}$ ) were thawed in $300 \mathrm{ml}$ argon-saturated $100 \mathrm{mM}$-Tris/HCl pH 8.5 buffer, containing $1 \mathrm{mg}$ lysosyme $\mathrm{ml}^{-1}$ and $0.1 \mathrm{mg}$ DNAase $\mathrm{ml}^{-1}$. The cells were incubated for $2 \mathrm{~h}$ at room temperature. The lysate was centrifuged under anaerobic conditions prior to centrifugation at $27600 \mathrm{~g}$ for $80 \mathrm{~min}$ at $4^{\circ} \mathrm{C}$, and the supernatant (soluble extract) was collected.

Ferredoxin-free extract. Soluble cell extract $(300 \mathrm{ml})$ was added to a DE52 (Whatman) column $(2 \mathrm{~cm} \times 13 \mathrm{~cm})$ equilibrated in $50 \mathrm{mM}$-Tris/ $\mathrm{HCl} \mathrm{pH} \mathrm{8.0.} \mathrm{The} \mathrm{column-bound} \mathrm{hydrogenase} \mathrm{was} \mathrm{washed}$ with six column volumes of equilibration buffer, before adding $0.13 \mathrm{M}-\mathrm{NaCl}$. At this salt concentration, the pale brown, hydrogenase- 
active band that eluted from the column was collected in $15 \mathrm{ml}$ fractions. Then buffer containing $0.28 \mathrm{M}-\mathrm{NaCl}$ was added, and a larger, more tightly bound brown band (containing the active pyruvateferredoxin oxidoreductase and hydrogenase) was collected in the same volume fractions. The ferredoxin, a dark brown band, was eluted with $1 \mathrm{M}-\mathrm{NaCl}$.

Pyruvate-ferredoxin oxidoreductase and hydrogenase. The pyruvateferredoxin-oxidoreductase-active and hydrogenase-active fractions from the above preparation were pooled and diluted 5:1 in

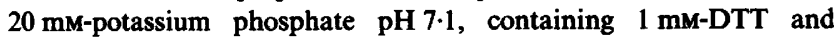
$0.05 \mathrm{mg} \mathrm{ml}^{-1}$ glucose oxidase. This was added to a hydroxylapatite (Bio-Gel HTP) column $(5.0 \mathrm{~cm} \times 2.5 \mathrm{~cm})$ equilibrated in the same buffer, and the column washed with 10 column volumes of the same buffer. Potassium phosphate buffer was then added as an increasing step-gradient, in $50 \mathrm{ml}$ aliquots, up to $0.5 \mathrm{M}$ in $0.1 \mathrm{M}$ increments. Pyruvate-ferredoxin oxidoreductase and hydrogenase eluted at potassium phosphate concentrations of $0.1 \mathrm{M}$ and $0.5 \mathrm{M}$ respectively.

Ferredoxin. The ferredoxin fraction from the above preparation was diluted with equilibration buffer and reconcentrated under oxygen-free nitrogen at $4^{\circ} \mathrm{C}$ in a $200 \mathrm{ml}$ Amicon pressure ultrafiltration vessel (10 kDa cut-off membrane). The resulting $30 \mathrm{ml}$ sample was passed down a second DE52 column $(1 \mathrm{~cm} \times 15 \mathrm{~cm})$, washed and eluted with a step-gradient (in 0.1 M increments) of 0.1-1.0 M- NaCl. A Sephadex G-75 column $(0.8 \mathrm{~cm} \times 50 \mathrm{~cm})$, equilibrated in the same buffer, was used to remove high-molecular-mass proteins and nucleic acids. Ferredoxin was reconcentrated by centrifugation at $2430 \mathrm{~g}$ in Amicon Centricon 10 microconcentrators, at $4^{\circ} \mathrm{C}$. The $A_{390} / A_{280}$ ratio was between 0.5 and 0.7 .

\section{Measurements of phosphoroclastic activity}

Measurement of hydrogen evolution in growing cell cultures. Actively growing cells $(60 \mathrm{ml})$ were inoculated into 11 of fresh medium, and the resultant culture was divided into $5 \mathrm{ml}$ volumes in sterile septum-sealed $27 \mathrm{ml}$ glass vials under nitrogen. Cultures, in triplicate, were incubated at $37^{\circ} \mathrm{C}$. After $4 \mathrm{~h}$ the inhibitor was added and the incubations continued. Samples of gas $(0.1 \mathrm{ml})$ were withdrawn at regular time intervals before and after the addition of inhibitor, and injected into a gas chromatograph with a thermal conductivity detector, previously calibrated with hydrogen

Assay of pyruvate-ferredoxin oxidoreductase and hydrogenase activity in growing cell cultures. Benzyl viologen was used instead of methyl viologen as terminal electron acceptor, because [benzyl viologen] ${ }^{+}$is a more permeant cation than [methyl viologen] ${ }^{+}$(Jones et al., 1976). Triton X-100 was also added to remove the permeability barrier. The assay mixture, prepared in $1 \mathrm{ml}$ septum-sealed cuvettes, contained $10 \mathrm{~mm}$-pyruvate, $200 \mu \mathrm{M}$-coenzyme A, $2 \mathrm{mM}$-thiamin pyrophosphate, $2 \mathrm{~mm}$-benzyl viologen and $2 \mathrm{mM}-\mathrm{MgCl}_{2}$ in $50 \mathrm{~mm}$-Tris/ $\mathrm{HCl}, \mathrm{pH} 8.0$. Hydrogenase activity was also monitored by spectrophotometric assay, using reaction mixtures which contained 2 mM-benzyl viologen, $2 \mathrm{mM}-\mathrm{DTT}$ and $0.4 \%$ Triton $\mathrm{X}-100$, in $50 \mathrm{mM}-\mathrm{Tris} / \mathrm{HCl}$, pH 7-0. The Triton X-100 was added to assays after they had been anaerobically prepared, as an argon-saturated concentrate. Other reagents for the assays of pyruvate-ferredoxin oxidoreductase and hydrogenase were bubbled for $20 \mathrm{~min}$ with oxygen-free argon or hydrogen respectively. All reactions were initiated by the addition of cells.

Determination of pyruvate-ferredoxin oxidoreductase and hydrogenase activity in cell extracts. These assays were the same as with whole cells, except that Triton X-100 was omitted, and $10 \mathrm{~mm}$-methyl viologen was used as terminal electron acceptor. The rate of reduction of methyl viologen was monitored spectrophotometrically at $604 \mathrm{~nm}$. One unit of enzyme activity (U) was calculated as one $\mu \mathrm{mol}$ of methyl viologen reduced $\mathrm{min}^{-1}$, i.e. twice the rate of hydrogen or pyruvate consumption.
Assay of nitrite reductase activity. A series of $1 \mathrm{ml}$ septum-sealed vials containing methyl viologen $(0.5 \mathrm{mM})$, dithionite $(5 \mathrm{mM})$ and nitrite $(0.25 \mathrm{mM})$ in $50 \mathrm{mM}$-phosphate buffer $\mathrm{pH} 7.0$ (in a total volume of $300 \mu \mathrm{l}$ ) were flushed under argon, prior to adding $50 \mu \mathrm{l}$ of crude extract. The reduction of nitrite was monitored at room temperature under argon. Reactions were stopped at $5 \mathrm{~min}$ intervals up to $90 \mathrm{~min}$, by adding $1 \mathrm{ml}$ of buffer, and assayed for nitrite using the Griess-Llosvay Nitrite Assay kit (BDH).

Protein assay. The protein concentration was determined by means of the Bio-Rad dye reagent assay, using gamma-globulin as standard. Absorbance readings were made at $595 \mathrm{~nm}$.

EPR spectroscopy. EPR samples were prepared of cell pellets, washed in argon-saturated $50 \mathrm{~mm}-\mathrm{Tris} / \mathrm{HCl} \mathrm{pH} \mathrm{8.0}$, and of supernatants. Spectra were recorded on a Varian E4 spectrometer with an Oxford Instruments ESR900 helium flow cryostat. Spin concentrations were determined by double integration with Cu-EDTA as standard. All EPR samples were studied at low temperature (below $20 \mathrm{~K}$ ) to monitor the integrity of iron-sulphur clusters in proteins after nitrite addition, and at higher temperatures (above $50 \mathrm{~K}$ ) to study [ $\mathrm{Fe}-\mathrm{S}-\mathrm{NO}$ ] formation.

\section{Results}

Effects of nitrate, nitrite and nitric oxide on whole cells of clostridia

Inhibition of exponential-phase growth. Oxoid nutrient broth no. 2 growth medium ( $\mathrm{pH} 7.4$ ) is widely used in the growth of many strains of clostridia and supports rapid cell growth. In our study, nitrite was added when cultures had reached a high density of cells $\left(3 \times 10^{7} \mathrm{ml}^{-1}\right)$ in exponential-phase growth. Experiments carried out under these conditions provided a stringent test of the ability of the antimicrobial agent used to inhibit active cell growth. When $1 \mathrm{mM}$-nitrate or $1 \mathrm{mM}$-nitrite (equivalent to concentrations permitted in foods) was included in the medium, growth of $C$. sporogenes was not

\section{Table 1. Inhibition of exponential-phase cultures of \\ C. sporogenes by nitrate, nitrite and nitric oxide}

Cell yield was calculated from values of wet weights of harvested cells after growth in the presence or absence of inhibitors. Each inhibitor was added as a filter-sterilized solution after $4 \mathrm{~h}$ of cell growth. Yield of control cells was $3 \mathrm{~g}$ litre $^{-1}$. Each culture (in triplicate) was inoculated into fresh normal growth medium after inoculation with inhibitor, to see if growth recovery occurred.

\begin{tabular}{lcc}
\hline \hline \multicolumn{1}{c}{ Inhibitor } & $\begin{array}{c}\text { Cell yield } \\
(\% \text { of control })\end{array}$ & $\begin{array}{c}\text { Growth in } \\
\text { fresh medium }\end{array}$ \\
\hline $1 \mathrm{mM}-\mathrm{NaNO}_{3}$ & 100 & yes \\
$1 \mathrm{mM}-\mathrm{NaNO}_{2}$ & 100 & yes \\
$4 \mathrm{mM}-\mathrm{NaNO}$ & 77 & yes \\
$0.5 \mathrm{~mm}-\mathrm{NaNO}_{2} / 4 \mathrm{mM}$-ascorbate & 64 & yes \\
$0.5 \mathrm{mM}-\mathrm{NaNO}_{2} / 10 \mathrm{mM}$-ascorbate & $<3$ & no \\
$0.186 \mathrm{mM}-\mathrm{Nitric}$ oxide & $<3$ & no \\
\hline
\end{tabular}

* Below this nitrate concentration, growth occurred. 


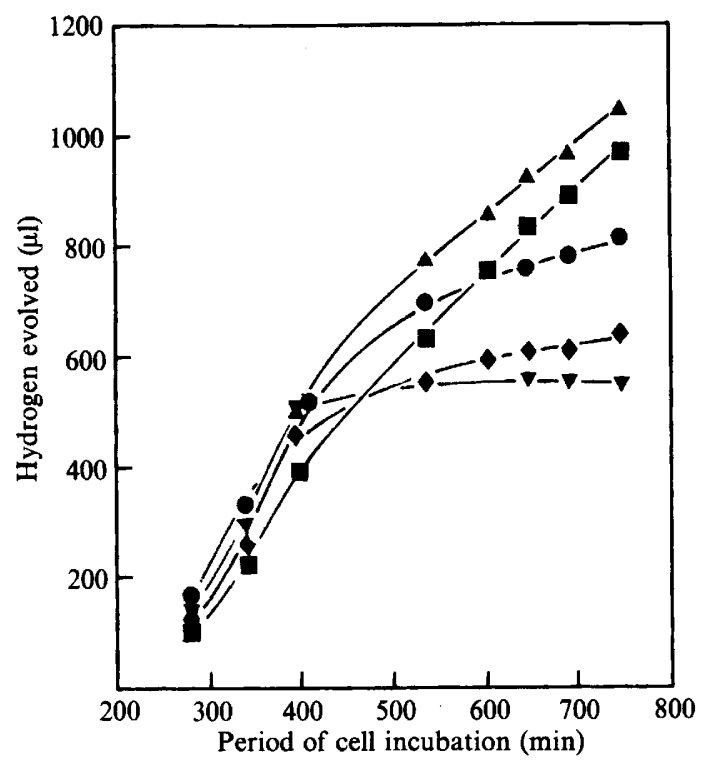

Fig. 1. Ascorbate enhancement of nitrite inhibition of hydrogen production in growing cell cultures. Nitrite and ascorbate were added after cells had been incubated at $37^{\circ} \mathrm{C}$ for $390 \mathrm{~min}$. $\mathrm{a}$, Control cell cultures (water added); $\Delta$, cultures $+0.5 \mathrm{mM}-\mathrm{NaNO}_{2} ; \diamond$, cultures + $0.5 \mathrm{~mm}-\mathrm{NaNO}_{2}$ and $4 \mathrm{~mm}$-ascorbate; $\nabla$, cultures $+0.5 \mathrm{~mm}-\mathrm{NaNO}_{2}$ and $10 \mathrm{mM}$-ascorbate; $\bullet$, cultures $+10 \mathrm{mM}$-ascorbate.

inhibited. With $4 \mathrm{~mm}$-nitrite in the medium, the cells continued to grow, with a yield of $77 \%$ of the control cultures but they formed agglutinated clumps when harvested, were difficult to resuspend, and were darker in colour than normal cultures. The increase in pigmentation appeared to be associated with insoluble cellular material. No residual nitrite was detected in the supernatant (growth medium) after growth with nitrite.

Nitrite in the presence of ascorbate was much more inhibitory than nitrite alone. Its concentration could be reduced to $0.5 \mathrm{mM}$ if the concentration of ascorbate was raised to $10 \mathrm{mM}$ (Table 1). Nitric oxide was also strongly inhibitory, even without added ascorbate, and $186 \mu \mathrm{M}$ concentrations totally inhibited clostridial growth. This is consistent with previous proposals (Tompkin et al., $1978 a, b$; Woods et al., 1981; Reddy et al., 1983), that the antimicrobial action of nitrite (in the absence of iron and cysteine) occurs via nitric oxide formation.

\section{Hydrogen production}

Nitrite inhibited hydrogen production far more efficiently than did nitrate. In the presence of increasing levels of ascorbate, nitrite inhibition was enhanced accordingly (Fig. 1).
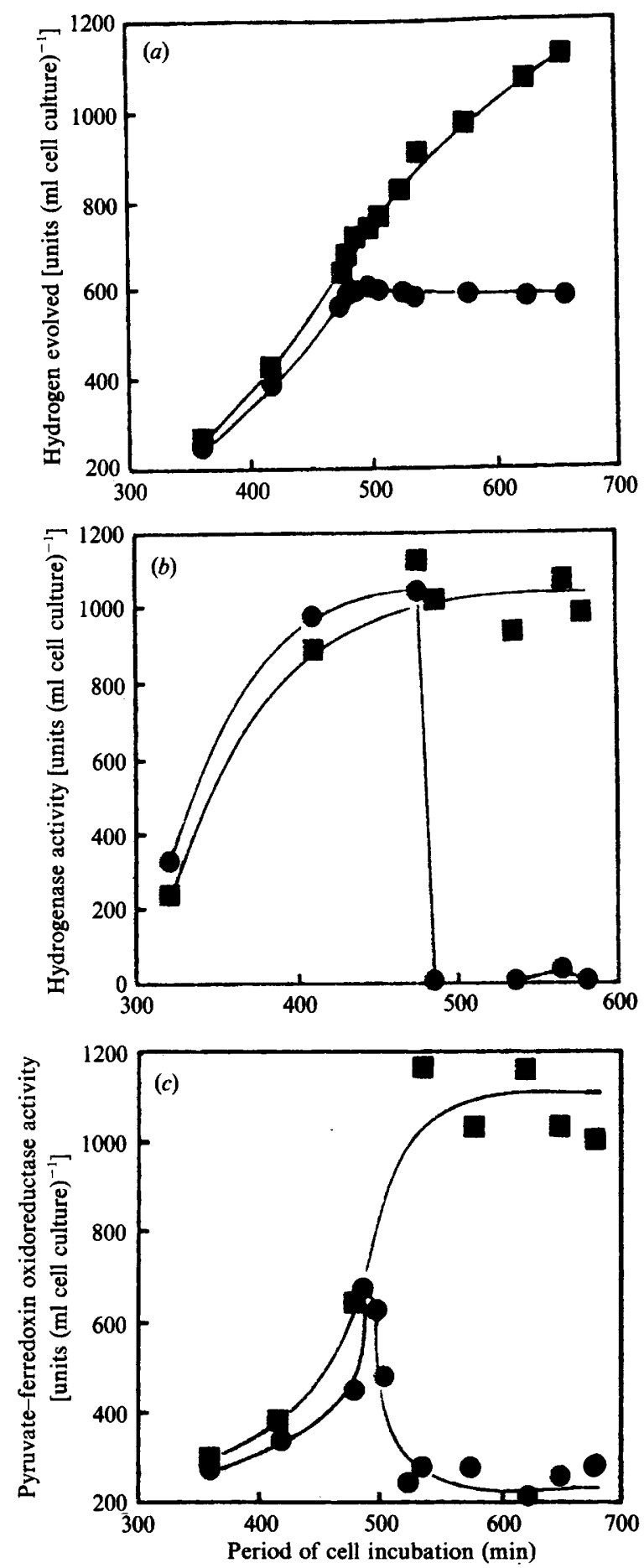

Fig. 2. Inhibition of hydrogen production, hydrogenase activity and pyruvate-ferredoxin-oxidoreductase activity by $1 \mathrm{~mm}-\mathrm{NaNO}_{2}$ and $4 \mathrm{~mm}$-ascorbate. Anaerobic nitrite solution was added to $5 \mathrm{ml}$ cultures of cells grown in septum-sealed $27 \mathrm{ml}$ vials, after $475 \mathrm{~min}$ of growth at $37^{\circ} \mathrm{C}$. Filter-sterilized water was added to control cultures. Samples of gas and of cells were withdrawn at regular time intervals under sterile conditions. Culture samples were assayed spectrophotometrically for pyruvate-ferredoxin oxidoreductase activity and hydrogenase activity, using Triton X-100 to lyse the cells. (a) Hydrogen production. (b) Hydrogenase activity. (c) Pyruvate-ferredoxin oxidoreductase activity. $\square$, Control cell cultures; $\bullet$, cell cultures $+1 \mathrm{mM}-\mathrm{NaNO}_{2}$ and 4 mM-ascorbate. 


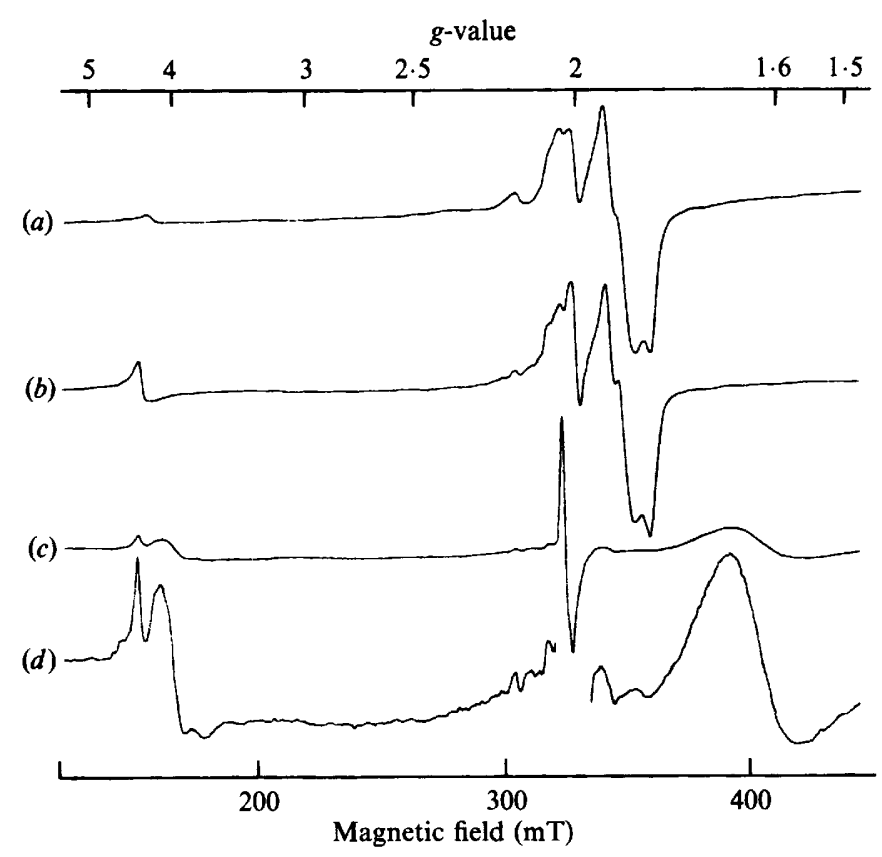

Fig. 3. EPR signals associated with interactions of whole cells of $C$. sporogenes with nitrite and ascorbate. (a) Cells as prepared (gain $\times 150$ ). (b) Cells after incubation with $15 \mathrm{~mm}-\mathrm{NaNO}_{2}$ at room temperature for $15 \mathrm{~min}$ (gain $\times 200$ ). (c) Cells after incubation with $15 \mathrm{mM}-\mathrm{NaNO}_{2}$ and $15 \mathrm{~mm}$-ascorbate for $30 \mathrm{~min}$ at room temperature $($ gain $\times 100)$. $(d)$ Sample as $(c)$, gain $\times 620$. Conditions of measurement: temperature $16 \mathrm{~K}$, microwave power $20 \mathrm{~mW}$, modulation amplitude $0.1 \mathrm{mT}$, microwave frequency $9.191 \mathrm{GHz}$.

\section{Hydrogenase activity}

When $1 \mathrm{~mm}-\mathrm{NaNO}_{2}$ and $4 \mathrm{~mm}$-ascorbate were added to growing cultures of $C$. sporogenes, hydrogenase activity was inhibited in the same time scale as hydrogen production (Fig. $2 a, b$ ). This indicated that the loss of hydrogen production could be accounted for by inhibition of hydrogenase.

\section{Pyruvate-ferredoxin oxidoreductase activity}

The addition of $1 \mathrm{~mm}-\mathrm{NaNO}_{2}$ and $4 \mathrm{~mm}$-ascorbate to growing cultures of $C$. sporogenes caused pyruvateferredoxin oxidoreductase activity to decrease, in a period of $1 \mathrm{~h}$, to a constant rate which was $22 \%$ of the control rate (Fig. 2c).

\section{Nitrite reductase activity}

Nitrite reductase activity in the crude cell extract was very low $\left(52 \mathrm{nmol} \mathrm{min}-1 \mathrm{mg}^{-1}\right)$. This suggested that, if the antimicrobial action of nitrite was through reduction to nitric oxide, then nitrite reductase would not readily form such a product. Hence inhibition of the growth of $C$. sporogenes was dependent on the addition of reducing agents.

\section{EPR spectroscopy}

EPR spectra, recorded at $16 \mathrm{~K}$, of cells grown under normal conditions showed signals with $g$-values of around 1.94, characteristic of proteins with reduced [4Fe-4S] clusters, such as ferredoxin. These signals are apparent in the wide-scan spectrum shown in Fig. 3(a). They were not observed at temperatures above $40 \mathrm{~K}$, owing to rapid electron-spin relaxation. When cells were incubated at room temperature with $15 \mathrm{~mm}$-nitrite for $15 \mathrm{~min}$, the EPR spectra showed that the iron-sulphur proteins remained in a reduced state (Fig. $3 b$ ). In some instances the $g=1.94$ signal decreased in size. There was also an increase in a signal at $g=4.3$ due to high-spin $\mathrm{Fe}^{3+}$ ions, which is a further indication of a more oxidized state. In general, it was observed that as long as the spectra indicated the presence of reduced 'ferredoxin-type' proteins $(g=1.94)$, the cells remained viable.

If cells were incubated with both $15 \mathrm{~mm}$-nitrite and $15 \mathrm{mM}$-ascorbate they were no longer viable. The EPR spectra of these cells no longer showed the $g=1.94$ signal due to $[4 \mathrm{Fe}-4 \mathrm{~S}]$ clusters (Fig. $3 c$ ), indicating that either oxidation or destruction of the clusters had occurred. A $g=2.03$ signal was also prominent. Another signal appeared at $g=4.0$; this is indicative of high-spin $\mathrm{Fe}-\mathrm{NO}$ formation and is associated with a weak downward feature at $g=2 \cdot 0$. In addition an unidentified broad signal appeared around $g=1.65$ (Fig. $3 d$ ). The signal was only detectable at temperatures of measurement below $40 \mathrm{~K}$.

EPR signals around $g=2.03$, induced by addition of nitrite to $C$. sporogenes cells, were larger in resting cells incubated with nitrite in vitro (such as in the experiments performed by Reddy et al., 1983), than in growing cells. In the absence of ascorbate, $3 \mathrm{~mm}-\mathrm{NaNO}_{2}$ induced nitrosyl formation in cells resuspended in buffer. Ascorbate stimulated the production of the nitrosyl complexes. EPR signals were observed after incubation of $C$. sporogenes with nitrite and ascorbate at $37^{\circ} \mathrm{C}$ for $1 \mathrm{~h}$, with nitrite concentrations ranging from $0.5 \mathrm{~mm}$ (which permits cell growth) to $5 \mathrm{~mm}$ (Fig. 4). However, if $3 \mathrm{mM}$-nitrite was introduced in vivo into fluid growth medium during cell growth, cells harvested after further overnight growth were devoid of EPR-detectable nitrosyl signals. $g=2.03$ signals were not detected in the supernatants from these cultures, even where $40 \mathrm{mM}$ nitrite and $40 \mathrm{~mm}$-ascorbate had been present. However, signals at $g=4.0$ and 2.0 were detected at $16 \mathrm{~K}$ in supernatants from cells grown in the presence of $10 \mathrm{mM}$-nitrite and equimolar ascorbate, which caused total growth inhibition. Signals of this type are character- 


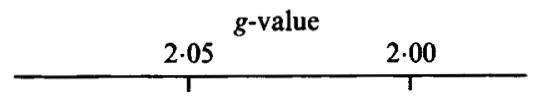

(a)

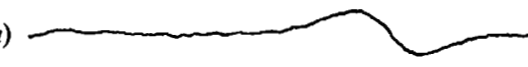

(b)

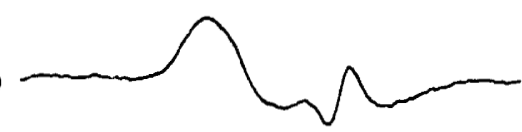

(c)

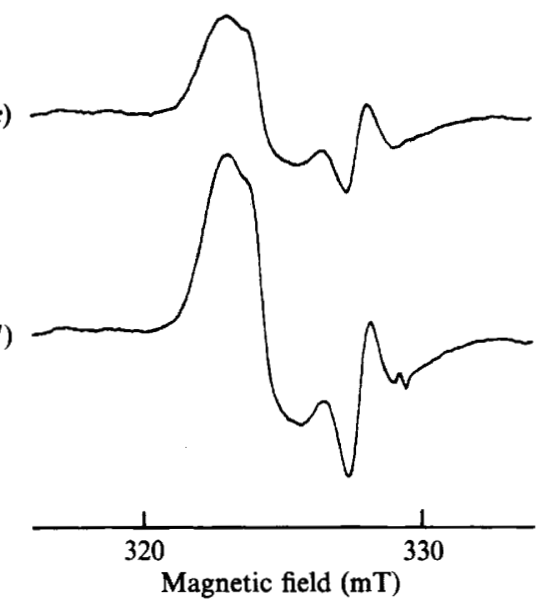

Fig. 4. EPR spectra showing nitrosyl formation in cells after incubation with nitrite and ascorbate. Cells $(a)$ as prepared, $(b)$ with $0.5 \mathrm{mM}-\mathrm{NaNO}_{2} /$ ascorbate added, (c) with $3 \mathrm{mM}-\mathrm{NaNO}_{2} /$ ascorbate added, (d) with $5 \mathrm{mM}-\mathrm{NaNO}_{2} /$ ascorbate added. Conditions of measurement: temperature $90 \mathrm{~K}$, microwave power $20 \mathrm{~mW}$, modulation amplitude $0.02 \mathrm{mT}$, microwave frequency $9.233 \mathrm{GHz}$, gain $\times 1000$.

istic of high-spin ferrous-nitrosyl complexes, in contrast to the low-spin $g=2.03$ species (Bonner et al., 1978; Rich et al., 1978).

\section{Inhibition of isolated iron-sulphur proteins}

Extract and purified enzyme samples were treated with nitrite in two ways: either extract was added directly to assay medium in which nitrite was present, or extract was incubated with nitrite prior to withdrawal of a sample for assay. In the latter case, nitrite was diluted into the assay medium by a factor of between 100- and 1000 -fold. By comparing the two conditions it was possible to determine whether inhibition was an immediate process, and whether it could readily be reversed.

The effects of $10 \mathrm{~mm}-\mathrm{NaNO}_{3}$ were observed on soluble extracts of $C$. sporogenes which were devoid of ferredoxin. Inhibition of pyruvate-ferredoxin oxidoreductase and hydrogenase activities only occurred in the presence of $10 \mathrm{~mm}$-ascorbate, indicating that reducing
Table 2. Inhibition of hydrogenase and pyruvate-ferredoxin oxidoreductase by nitrite derivatives

Soluble extract from $C$. sporogenes was incubated with each inhibitor at room temperature for $15 \mathrm{~min}$ prior to assay. Each assay was performed a minimum of 3 times. Control specific activity of pyruvate-ferredoxin oxidoreductase and hydrogenase was 0.20 units $\mathrm{mg}^{-1}$ and 0.06 units $\mathrm{mg}^{-1}$ respectively, where 1 unit was equivalent to $1 \mu \mathrm{mol}$ of methyl viologen reduced $\mathrm{min}^{-1}$.

\begin{tabular}{|c|c|c|}
\hline \multirow[b]{2}{*}{ Addition(s) } & \multicolumn{2}{|c|}{ Specific activity (\% of control) } \\
\hline & $\begin{array}{c}\text { Pyruvate- } \\
\text { ferredoxin } \\
\text { oxidoreductase }\end{array}$ & Hydrogenase \\
\hline $1.64 \mathrm{~mm}-\mathrm{NaNO}_{3}$ & 100 & 100 \\
\hline $4 \cdot 1 \mathrm{mM}-\mathrm{NaNO}_{3}$ & 100 & ND \\
\hline $10 \mathrm{mM}-\mathrm{NaNO}_{3}$ & 100 & 96 \\
\hline $4 \cdot 1 \mathrm{~mm}-\mathrm{NaNO}_{3}+4 \cdot 1 \mathrm{mM}$-ascorbate & 74 & ND \\
\hline $10 \mathrm{mM}-\mathrm{NaNO}_{3}+10 \mathrm{mM}$-ascorbate & 68 & 64 \\
\hline $0.5 \mathrm{mM}-\mathrm{NaNO}_{2}$ & 90 & ND \\
\hline $1.64 \mathrm{mM}-\mathrm{NaNO}_{2}$ & 79 & 68 \\
\hline $4.1 \mathrm{~mm}-\mathrm{NaNO}_{2}$ & 32 & 28 \\
\hline $4.1 \mathrm{mM}-\mathrm{NaNO}_{2}+4 \cdot 1 \mathrm{mM}$-ascorbate & 29 & $\mathbf{0}$ \\
\hline $1.64 \mathrm{mM}-\mathrm{Nitric}$ oxide & 39 & 21 \\
\hline
\end{tabular}

ND, Not determined.

conditions were necessary. $\mathrm{NaNO}_{2}$ at $0.5 \mathrm{~mm}$ concentration, which is comparable with the amounts used in foodstuffs, caused $10 \%$ inhibition of pyruvateferredoxin oxidoreductase activity (Table 2).

At higher concentrations of $\mathrm{NaNO}_{2}$, inhibition of pyruvate-ferredoxin oxidoreductase activity was rapid and irreversible, but incomplete. After $\mathrm{NaNO}_{2}$ was incubated with pyruvate-ferredoxin oxidoreductase, and then diluted into the assay medium, activity did not recover, despite the 100 -fold dilution of the inhibitor. However, prolonged incubation of the enzyme with $\mathrm{NaNO}_{2}$ did not increase the degree of inhibition. $\mathrm{NaNO}_{3}, \mathrm{NaNO}_{2}$ and $\mathrm{NO}$ had a greater effect on hydrogenase activity than on pyruvate-ferredoxin oxidoreductase activity (Table 2). Hydrogenase activity when measured in the presence of DTT (which protected the enzyme) was severely but not totally $(92 \%)$ inhibited by $5 \mathrm{~mm}$-nitrite and $5 \mathrm{~mm}$-ascorbate (Table 3), both in the presence and absence of ferredoxin $\left(0.02 \mathrm{mg} \mathrm{ml}^{-1}\right.$ assay). Nitric oxide at $1.64 \mathrm{mM}$ concentration did not totally inhibit pyruvate-ferredoxin oxidoreductase or hydrogenase activity. Growth of $C$. sporogenes was totally inhibited by $0.5 \mathrm{mM}$-nitrite and $10 \mathrm{~mm}$ ascorbate, or by $0.186 \mathrm{mM}$-nitric oxide (Table 1). Therefore the antimicrobial effect of nitrite or nitric oxide cannot be explained by direct inhibition of preformed pyruvate-ferredoxin oxidoreductase or hydrogenase. 
Table 3. Enhancement of pyruvate-ferredoxin oxidoreductase or hydrogenase activity by normal and nitrite-treated ferredoxin

Soluble extract devoid of ferredoxin was used in these assays. Pyruvate-ferredoxin oxidoreductase and hydrogenase assay mixtures had various combinations of $0.02 \mathrm{~mm}$-ferredoxin $(\mathrm{Fd})$, $5 \mathrm{~mm}$-DTT, and $5 \mathrm{~mm}-\mathrm{NaNO}_{2}$ with $5 \mathrm{~mm}$-ascorbate added to them. Assays were performed at $30^{\circ} \mathrm{C}$.

\begin{tabular}{|c|c|c|}
\hline $\begin{array}{l}\text { Reagent(s) } \\
\text { added } \\
\text { to assay }\end{array}$ & $\begin{array}{c}\text { Mean sp. activity } \\
\text { of hydrogenase } \\
{\left[U \mathrm{mg}^{-1} \pm \mathbf{S D}(3)\right]}\end{array}$ & $\begin{array}{l}\text { Percentage } \\
\text { inhibition } \\
\text { of activity }\end{array}$ \\
\hline $\begin{array}{l}\text { None (control) } \\
\text { DTT } \\
\text { DTT + Fd } \\
\text { DTT + NaNO }+ \text { ascorbate } \\
\text { DTT + Fd }+\mathrm{NaNO}_{2}+\text { ascorbate }\end{array}$ & $\begin{array}{l}0.387 \pm 0.025 \\
0.478 \pm 0.049 \\
0.515 \pm 0.072 \\
0.039 \pm 0.007 \\
0.043 \pm 0.004\end{array}$ & $\begin{array}{l}92 \\
92\end{array}$ \\
\hline \multicolumn{3}{|c|}{$\begin{array}{l}\text { Mean sp. act. of pyruvate-ferredoxin } \\
\text { oxidoreductase }\left(\mathrm{U} \mathrm{mg}^{-1}+\mathrm{SD}\right)\end{array}$} \\
\hline $\begin{array}{l}\text { None (control) } \\
\mathrm{Fd} \\
\mathrm{NaNO}_{2}+\text { ascorbate } \\
\mathrm{Fd}+\mathrm{NaNO}_{2} \\
\text { Ascorbate }\end{array}$ & $\begin{array}{l}2.70 \pm 0.15 \\
4.50 \pm 0.007 \\
1.70 \pm 0.03 \\
2.90 \pm 0.05\end{array}$ & $\begin{array}{l}37 \\
36\end{array}$ \\
\hline
\end{tabular}

Ferredoxin enhanced the pyruvate-methyl-viologen oxidoreductase activity of pyruvate-ferredoxin oxidoreductase. Preincubation of ferredoxin (prior to assay) with $5 \mathrm{mM}-\mathrm{NaNO}_{2}$ (Table 3) had no significant effect on this enhancement.

\section{Effects of nitrite on EPR spectroscopic properties of iron- sulphur proteins}

When soluble extract from $C$. sporogenes cells was incubated with $14 \mathrm{mM}-\mathrm{NaNO}_{2}$ and $14 \mathrm{~mm}$-ascorbate, iron-nitrosyl signals were detected at $16 \mathrm{~K}$ with $g$-values of 2.03 (Fig. 5). An additional unidentified signal was observed at $g=1 \cdot 65$. Both signals were detected under these conditions, but there was no correlation in their amplitudes in different samples, indicating that they are from different species. The $g=1.65$ signal was not observed in cells after growth with concentrations of equimolar nitrite and ascorbate below $3 \mathrm{~mm}$, but was of particular interest because in our studies (Payne et al., 1990), similar signals have been observed in cells grown in the presence of $[\mathrm{Fe}-\mathrm{S}-\mathrm{NO}]$ complexes, where only micromolar levels of nitrite were available. If the signal is related to a cellular interaction, this may suggest that very high nitrite levels are necessary to form this signal when the $\mathrm{Fe}$ and $\mathrm{S}$ source (for [ $\mathrm{Fe}-\mathrm{S}-\mathrm{NO}]$ formation) is a protein. Therefore, total extraction of these iron-sulphur centres by nitrite may be more difficult than anticipated

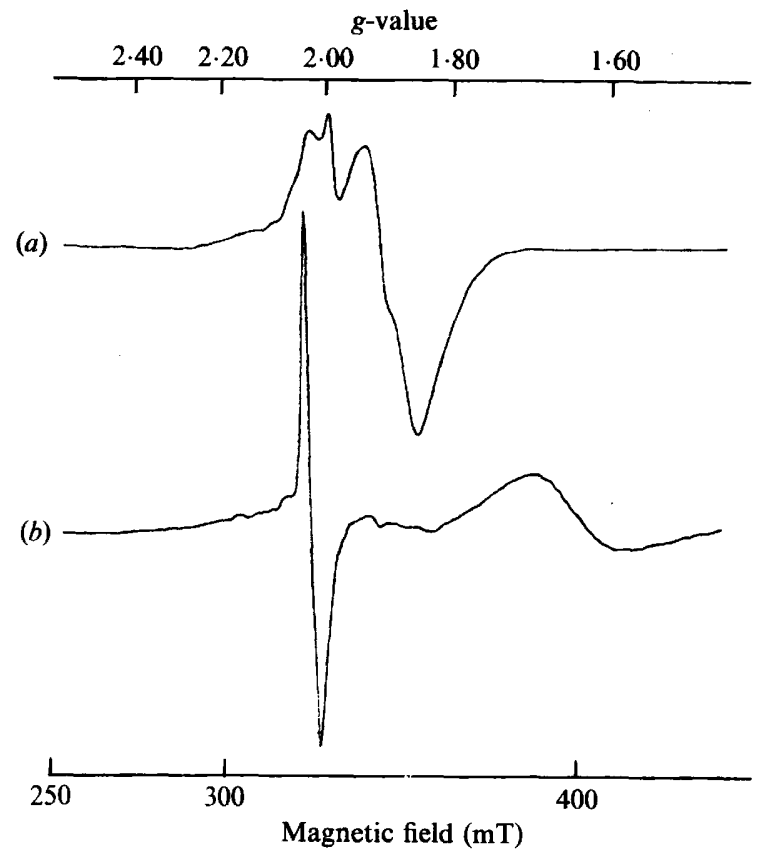

Fig. 5. EPR-detectable nitrosyl formation in nitrite-treated extract of C. sporogenes. (a) Soluble extract as prepared. (b) Incubated with $14 \mathrm{~mm}-\mathrm{NaNO}_{2}$ and $14 \mathrm{~mm}$-ascorbate at room temperature for $15 \mathrm{~min}$. Conditions of measurement: temperature $16.5 \mathrm{~K}$, microwave power $20 \mathrm{~mW}$, modulation amplitude $0.1 \mathrm{mT}$, microwave frequency $9 \cdot 193 \mathrm{GHz}$, gain $\times 200$.

by Angermaier \& Simon (1983). The signals appear to have a close association with cell damage and pigmentation. After an extract devoid of ferredoxin was incubated with $1.1 \mathrm{~mm}-\mathrm{NO}$, the same signal was observed, indicating that it was independent of the presence of ferredoxin.

A cell extract, containing pyruvate-ferredoxin oxidoreductase and hydrogenase activity, but devoid of ferredoxin, was incubated with $4 \mathrm{~mm}$-nitrite and $4 \mathrm{mM}$-ascorbate, and yielded EPR spectra with $g=2.03$ signals, indicative of $[\mathrm{Fe}-\mathrm{S}-\mathrm{NO}]$ species. At these concentrations of nitrite and ascorbate, pyruvateferredoxin oxidoreductase and hydrogenase activities were severely inhibited (Table 2), and therefore nitrite interaction with $[4 \mathrm{Fe}-4 \mathrm{~S}]$ centres in these proteins could have been responsible for nitrosyl formation.

After incubating ferredoxin isolated from $C$. sporogenes with $3.6 \mathrm{mM}-\mathrm{NaNO}_{2}$ and equimolar ascorbate for $1 \mathrm{~h}$ at room temperature, EPR spectra of the reduced protein at $15 \mathrm{~K}$ (data not shown) still showed the presence of normal amounts of reduced [4Fe-4S] centres at $g=1.94$. Therefore reduced ferredoxin appears to be relatively stable to attack by nitrite. 


\section{Discussion}

\section{Relevance of nitrite concentrations used}

Concentrations of nitrite added to meats are mainly written as p.p.m. quantities, or $\mathrm{mg}$ nitrite $(\mathrm{kg} \text { liver) })^{-1}$, etc. For the sake of this study the literature values were calculated into millimolar amounts, assuming that $1 \mathrm{~kg}$ of meat was equal in volume to $1 \mathrm{~kg}$ of water. The values calculated were therefore somewhat underestimated, compared with nitrite concentrations added to meat. Concentrations of nitrite previously found necessary to inhibit clostridial growth in liquid growth medium have ranged from $4.4 \mathrm{mM}$ at $\mathrm{pH} 7.0$ to $7.0 \mathrm{mM}$ at $\mathrm{pH} 7.5$ (Roberts \& Ingram, 1966; Perigo et al., 1967; Perigo \& Roberts, 1968; Baird-Parker \& Baillie, 1973; O'Leary \& Solberg, 1976; Woods et al., 1981). We have similarly shown that $C$. sporogenes readily grow in liquid cultures in the presence of nitrite, at concentrations above those used in food preservation (Pierson \& Smoot, 1981; Knight et al., 1987), i.e. $>2.3 \mathrm{~mm}$.

\section{Effectiveness of ascorbate with nitrite}

Ascorbate acted synergistically with nitrite to inhibit cell growth. Baird-Parker \& Baillie (1973) were able to decrease the minimum inhibitory concentration of nitrite for all strains of clostridia to around $1.5 \mathrm{~mm}$ using ascorbate at concentrations between $5.7 \mathrm{mM}$ and $57 \mathrm{~mm}$. In the present study, $0.5 \mathrm{~mm}$ nitrite was adequate, with $10 \mathrm{~mm}$ ascorbate, despite high cell density. Direct interaction of nitric oxide with iron-sulphur centres in proteins may have been responsible for inhibition of cell growth (resulting in [Fe-S-NO] formation). Nitric oxide was far more efficient at inhibiting growth than nitrite and ascorbate. This suggests that the formation of nitric oxide by reduction of nitrite by ascorbate is not very efficient.

\section{How are cells killed?}

The pigmentation of insoluble cell components after cell growth with nitrite is in agreement with observations made by O'Leary \& Solberg (1976), who found that C. perfringens cells inhibited by $14 \mathrm{~mm}-\mathrm{NaNO}_{2}$ were dark grey/brown in colour, exhibited a different mass consistency and were harder to disperse in buffer. The pigmentation appeared to be associated with cell walls or membranes, and it was proposed that such damage could be a primary event in cell death.

\section{EPR-detectable $\mathrm{Fe}-\mathrm{NO}$ complexes}

Reddy et al. (1983) observed that iron-nitrosyl $(g=2.03)$ signal formation in $C$. botulinum, after treatment with
$2.9 \mathrm{~mm}-\mathrm{NaNO}_{2}$ and equimolar ascorbate, occurred simultaneously with the disappearance of EPR signals $(g=1.94$ at $16 \mathrm{~K})$ indicative of reduced [ $4 \mathrm{Fe}-4 \mathrm{~S}]$ centres. They suggested that the antimicrobial activity of nitrite depended on 'inhibition of electron-transfer processes in general, by destruction of iron-sulphur centres'. However, we have observed that iron-nitrosyl signal formation does not correlate with growth inhibition in C. sporogenes. We have also observed that, in our cell preparations, $g=1.94$ signals at $16 \mathrm{~K}$ are present after incubation of $3 \mathrm{mM}-\mathrm{NaNO}_{2}$ with equimolar ascorbate. These signals were smaller than those found in uninhibited cell samples, but this may have been partially due to sample oxidation by nitrite. Generally, actively growing $C$. sporogenes exhibited EPR spectra indicative of reduced iron-sulphur proteins, and strongly inhibited cells showed spectra characteristic of oxidized ironsulphur proteins. However, low-spin ferrous-nitrosyl signals were often present in both cases.

Woods et al. (1981) detected an accumulation of pyruvate in the medium after incubation of resuspended cells with $4.4 \mathrm{mM}-\mathrm{NaNO}_{2}$, and attributed this to direct inhibition of pyruvate-ferredoxin oxidoreductase by nitrite. Our results agree with Woods et al. (1981), in the finding that pyruvate-ferredoxin oxidoreductase activity is more significantly inhibited than ferredoxin by nitrite, and that the oxidoreductase is more readily inhibited by nitrite in vivo than in vitro. We have shown that nitrite and ascorbate, at concentrations higher than those used in the food industry, do not cause total destruction of [4Fe-4S] clusters in preformed proteins. Carpenter et al. (1987) reported that ferredoxin activity was damaged to a greater extent than pyruvate-ferredoxin oxidoreductase. However, they used high concentrations of nitrite (14.5 mM), and did not achieve total inhibition in either case. Our EPR spectroscopic studies indicate that the purified protein, if isolated under strictly anaerobic conditions, is remarkably resistant to nitrite.

Nitrite has been proposed to specifically inhibit these ferredoxin-type enzymes as part of its antimicrobial action (Tompkin et al., 1978 a; Woods et al., 1981 ; Reddy et al., 1983; Carpenter et al., 1987). This study has provided evidence that EPR-detectable iron-nitrosyls are indeed formed when nitrite is incubated with extract at high concentration. However, the importance of this process in the antimicrobial activity of nitrite is in dispute. The concentration of nitrite necessary to achieve inhibition is higher than would be present in conditions of food preservation.

Inhibition by nitrite of pyruvate-ferredoxin oxidoreductase was found to be only partial; while $78 \%$ of the activity was readily destroyed, the remaining activity was stable. Similarly, Carpenter et al. (1987) reported only $70 \%$ inhibition of pyruvate-ferredoxin oxido- 
reductase activity after incubating the enzyme with $14.5 \mathrm{mM}-\mathrm{NaNO}_{2}$. This effect could be explained if there existed two forms of pyruvate-ferredoxin oxidoreductase, one resistant and the other susceptible to nitrite attack. One form may be totally inactivated while the other is less susceptible to inhibition. Uyeda \& Rabinowitz (1971), during purification of pyruvateferredoxin oxidoreductase from $C$. acidi-urici, found that activity was separated into a $70 \%$ unstable fraction and a $30 \%$ stable fraction.

It is not clear if the inhibition of pyruvate-ferredoxin oxidoreductase activity by nitrite would be significant in vivo. We have previously shown that pyruvate-ferredoxin oxidoreductase activity is protected from attack by nitrite by its substrate, pyruvate (Payne \& Cammack, 1986).

Clostridia are able to generate various 2-oxoacids from exogenous fatty acid homologues containing one carbon atom less. The fatty acids appear to be activated by a kinase, and the fatty acyl-phosphates formed are metabolized to their CoA derivatives, which are the substrate for the ferredoxin-linked reductive carboxylation system (cf. James et al., 1988). During our purification of pyruvate-ferredoxin oxidoreductase, phenyl pyruvate, 2-oxopentanoate, 2-oxobutyrate, 2-oxoisovalerate, 2-oxoisocaproate, 2-oxooctanoate and oxaloacetate-oxidizing ability were found to be present in cell extracts. It is not known if any of these activities are associated with iron-sulphur proteins. However, the activities were found to be inhibited to varying degrees (none of them totally) by $10 \mathrm{mM}-\mathrm{NaNO}_{2}$ and equimolar ascorbate.

Inhibition of hydrogen production in vivo occurred in parallel with inhibition of hydrogenase activity. We have shown that hydrogenase is the most sensitive ironsulphur enzyme in the phosphoroclastic system to nitrite attack. Inhibition of hydrogen production during cell growth might therefore occur through interaction of either nitrite or nitric oxide with the hydrogenase enzyme. Recent studies on the hydrogenases of C. pasteurianum have shown that there are two different enzymes, one specifically catalysing hydrogen uptake and the other bidirectional. Each contains an unusual, highly oxygen-sensitive iron-sulphur cluster, possibly containing six iron atoms, which is probably the site of hydrogen binding (Adams et al., 1989). Studies on the hydrogenases of Desulfovibrio spp. have shown that the enzymes that contain only iron-sulphur clusters are more sensitive to inhibition by nitric oxide than are those that contain nickel as well as iron-sulphur clusters (Berlier $e t$ al. 1987).

Hydrogenase activity may not be absolutely essential to cell growth. Even total inhibition of hydrogen production may only result in a decrease in the rate of cell growth, and an alteration of the products of metabolism. Meyer et al. (1986) found that when cultures of C. acetobutylicum were gassed with carbon monoxide, hydrogen production was totally inhibited. The alteration in electron transport triggered solvent (butanol and ethanol) formation and inhibited acetate and butyrate production. The authors concluded that electrons normally used for hydrogen formation were used for solvent production instead. Perhaps nitrite inhibition of hydrogenase in vivo may trigger a similar alteration in electron transport.

We thank Mr A. J. Quinn who developed some of the assay methods used in this investigation, and Miss J. E. Bell for studies on the oxoacidferredoxin reductases. This work was supported by a postgraduate award from the Ministry of Agriculture, Fisheries and Food to M.J.P. and by grants from the Agricultural and Food Research Council and the Science and Engineering Research Council to R.C.

\section{References}

AdaMs, M. W. W., Eccleston, E. \& Howard, J. B. (1989). Ironsulphur clusters of hydrogenase I and hydrogenase II of Clostridium pasteurianum. Proceedings of the National Academy of Sciences of the United States of America 86, 4932-4936.

ANGERMAIER, L. \& SimON, H. (1983). On the reduction of aliphatic and aromatic nitro compounds by clostridia; the role of ferredoxin in its stabilisation. Hoppe-Seyler's Zeitschrift für Physiologische Chemie 364S, 961-975.

ASAN, T. \& SOLBERG, M. (1976). Inhibition of Clostridium perfringens by heated combinations of nitrite, sulfur and ferrous or ferric ions. Applied and Environmental Microbiology 31, 49-52.

Baird-Parker, A. C. \& Baillie, M. A. H. (1973). The inhibition of Clostridium botulinum by nitrite and sodium chloride. Proceedings of the International Symposium on Nitrite Meat Products II, 77-91.

Berlier, Y., Fauque, G. D., Le Gall, J., Choi, E. S., Peck, H. D. \& LESPINAT, P. A. (1987). Inhibition studies of three classes of Desulfovibrio hydrogenase - application to the further characterisation of the multiple hydrogenases found in $D$. vulgaris Hildenborough. Biochemical and Biophysical Research Communications 146, 147-154.

Bonner, W. D., JR, Blum, H., Rich, P. R. \& Salerno, J. C. (1978). Further observation on mitochrondrial metallocompound and on a ferrous-EDTA-NO model compound. In Frontiers of Biological Energetics, pp. 997-1001. London: Academic Press.

ButleR, A. R., Glidewell, C. \& LI, M.-H. (1988). Nitrosyl complexes of irọn-sulphur clusters. In Advances in Inorganic Chemistry, pp. 335-393. Edited by A. G. Sykes. London: Academic Press.

Carpenter, C. E., Reddy, D. S. \& Cornforth, D. P. (1987). Inactivation of clostridial ferredoxin and PFR by sodium nitrite. Applied and Environmental Microbiology 53, 549-552.

JAMES, E. W., Kell, D. B., LovitT, R. W. \& MorRis, J. G. (1988). Electrosynthesis and electroanalysis using Clostridium sporogenes. Bioelectrochemistry and Bioenergetics 20, 21-32.

Jones, R. W., Gray, T. A. \& Garland, P. B. (1976). A study on the permeability of the cytoplasmic membrane of $E$. coli to reduced and oxidised benzyl viologen and methyl viologen cations; complications in the use of viologens as redox mediators for membrane bound enzymes. Biochemical Society Transactions 4, 671-673.

Knight, T. M., Forman, D., Al-DabbaGh, S. A. \& Doll, R. (1987). Estimation of dietary intake of nitrate and nitrite in Great Britain. Food and Chemical Toxicology 25, 277-285.

LARkWORThy, L. F., TURnBulL, M. H. \& YaVarı, A. (1977). Possible role of iron II amino acid complexes in nitrite depletion and inhibitor formation in cured meats. Chemistry and Industry, May 21st, $401-402$. 
McDonald, C. C., Phillips, W. D. \& Mower, H. F. (1965). An electron spin resonance study of some complexes of iron, nitric oxide and anionic ligands. Journal of the American Chemical Society 87, 3319-3326.

MeYer, C. L., Roos, J. W. \& Papoutsakis, L. (1986). CO gassing leads to alcohol production and butyrate uptake without acetone formation in continuous cultures of Clostridium acetobutylicum. Applied Microbiology and Biotechnology 24, 159-167.

O'LeARY, V. \& SOLBERG, M. (1976). Effect of sodium nitrite inhibition on intracellular thiol groups and on activity of certain glycolytic enzymes in Clostridium perfringens. Applied and Environmental Microbiology 31, 208-212.

Payne, M. J. \& Cammack, R. (1986). Inhibition by nitrite of the phosphoroclastic system of Clostridium sporogenes. Biochemical Society Transactions 14, 1283-1284.

Payne, M. J., Glidewell, C. \& Cammack, R. (1990). Interaction of iron-thiol-nitrosyl compounds with the phosphoroclastic system of Clostridium sporogenes. Journal of General Microbiology 136, 2077-2087.

Perigo, J. A. \& Roberts, T. A. (1968). Inhibition of clostridia by nitrite. Journal of Food Technology 3, 91-94.

Perigo, J. A., Whiting, E. \& BASHFord, T. E. (1967). Observations on the inhibition of vegetative cells of Clostridium sporogenes by nitrite which has been autoclaved in a laboratory medium, discussed in the context of sub-lethally processed cured meats. Journal of Food Technology 2, 377-397.

PIERSON, M. D. \& SMOOT, L. A. (1981). Nitrite, nitrite alternatives and the control of Clostridium botulinum in cured meats. CRC Critical Reviews in Food Science and Nutrition 17, 141-187.

REDDY, D., LANCASTER, J. R., JR \& CORNFORTH, D. P. (1983). Nitrite inhibition of Clostridium botulinum; Electron spin resonance detection of iron-nitric oxide complexes. Science 221, 769-770.
Rich, P. R., SAlerno, J. C., Leigh, J. S. \& Bonner, W. D., JR (1978). $A$ spin $3 / 2$ ferrous-NO derivative of an iron containing moiety associated with Neurospora crassa and higher plant mitochondria. FEBS Letters 93, 323-326.

RoBERTS, T. A. \& INGRAM, M. (1966). The effect of sodium chloride, potassium nitrate and sodium nitrite on the recovery of heated bacterial spores. Journal of Food Technology 1, 147-163.

Tomprin, R. B., Christiansen, L. N. \& Shaparis, A. B. (1978a). Antibotulinal role of isoascorbate in cured meats. Journal of Food Science 43, 1368-1370.

Tompkin, R. B., Christiansen, L. N. \& Shaparis, A. B. (1978b) Enhancing nitrite inhibition of Clostridium botulinum with isoascorbate in perishable canned cured meat. Applied and Environmental Microbiology 35, 59-61.

Tomprin, R. B., Christiansen, L. N. \& Shaparis, A. B. (1978c). The effect of iron on botulinal inhibition in perishable canned cured meat. Journal of Food Technology 13, 521-527.

UYEDA, K. \& RABINOWITZ, J. C. (1971). Pyruvate:ferredoxin oxidoreductase. IV. Studies on the reaction mechanism. Journal of Biological Chemistry 246, 3120-3125.

VANIN, A. F. \& VARICH, V. YA. (1981). Nitrosyl non-heme iron complexes in animal tissues. Studia Biophysica 86, 177-185.

Woods, L. F. J. \& Wood, J. M. (1982). A note on the effect of nitrite inhibition on the metabolism of Clostridium botulinum. Journal of Applied Bacteriology 52, 109-110.

Woods, L. F. J., Wood, J. M. \& GibBs, P. A. (1981). The involvement of nitric oxide in the inhibition of the phosphoroclastic system in Clostridium sporogenes by sodium nitrite. Journal of General Microbiology 125, 399-406. 